Available online on 15.09.2017 at http://iddtonline.info
C 2011-17, publisher and licensee JDDT, This is an Open Access article which permits unrestricted
noncommercial use, provided the original work is properly cited

Open $\odot$ Access

Research Article

\title{
ANTIBACTERIAL AND ANTIFUNGAL ACTIVITY OF THREE RAMALINA SPECIES
}

\author{
Ankith GN ${ }^{1}$, Rajesh MR ${ }^{1}$, Karthik KN ${ }^{1}$, Avinash HC ${ }^{1}$, Prashith Kekuda T.R ${ }^{1 *}$, Vinayaka KS ${ }^{2}$ \\ ${ }^{1}$ Department of Microbiology, S.R.N.M.N College of Applied Sciences, N.E.S Campus, Balraj Urs Road, Shivamogga-577201, Karnataka, \\ India \\ ${ }^{2}$ Department of Botany, Kumadvathi First Grade College, Shikaripura, Shivamogga-577427, Karnataka, India
}

\begin{abstract}
Lichens are an association of a photobiont (an alga or a cyanobacterium) and a mycobiont (a fungus). The lichen genus Ramalina is one of the cosmopolitan lichen genera and is characterized by fruticose thallus. In the present study, an antibacterial and antifungal activity of an extract of three Ramalina species (Ramalinaceae) viz. $R$. hossei Vain, $R$. conduplicans Vain and $R$. pacifica Asahina obtained by maceration process were investigated. The lichens were collected from different places of Shivamogga district, Karnataka, India and identified on the basis of morphological, anatomical and chemical tests. The antibacterial and antifungal activity of lichen extracts was carried out by Agar well diffusion and Poisoned food technique respectively. Overall, B. cereus and E. coli were inhibited to higher extent and least extent respectively by extracts of Ramalina species. R. pacifica and $R$. hossei inhibited bacteria to highest and least extent respectively. In the case of antifungal activity, marked and least inhibitory activity was shown by an extract of $R$. hossei and $R$. pacifica respectively. Among fungi, Alternaria sp. and Fusarium sp. were inhibited to highest and least extent respectively. The observed antimicrobial potential could be ascribed to the presence of secondary metabolites such as usnic acid, salazinic acid and sekikaic acid present in the Ramalina species.
\end{abstract}

Key words: Lichens, Ramalina, Antimicrobial, Agar well diffusion, Poisoned food technique

Article Info: Received 26 July, 2017; Review Completed 17 Aug, 2017; Accepted 17 Aug, 2017; Available online 15 Sep, 2017

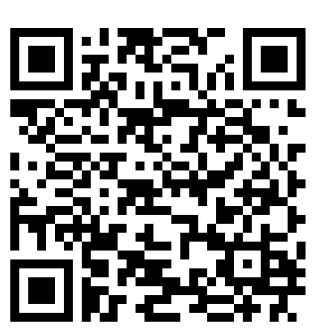

Cite this article as:

Ankith GN, Rajesh MR, Karthik KN, Avinash HC, Prashith Kekuda TR, Vinayaka KS, Antibacterial and antifungal activity of three ramalina species, Journal of Drug Delivery and Therapeutics. 2017; 7(5):27-32

DOI: http://dx.doi.org/10.22270/jddt.v7i5.1501

*Address for Correspondence

Dr. Prashith Kekuda T.R, Department of Microbiology, S.R.N.M.N College of Applied Sciences, N.E.S Campus, Balraj Urs Road, Shivamogga-577201, Karnataka, India, Email: p.kekuda@gmail.com

\section{INTRODUCTION}

The development of resistance in bacteria has become one of the major global problems. Bacteria develop resistance against antibiotics in relatively shorter period of time making the therapy of diseases more difficult. Bacteria such as Staphylococcus aureus, Streptococcus pneumoniae, Enterococci, Pseudomonas aeruginosa, Escherichia coli, Klebsiella pneumoniae and Mycobacterium tuberculosis are among the many drug resistant bacteria. Unrestrained use of antibiotics and the ability of pathogenic bacteria to spread the resistance gene to susceptible strains by genetic means are resulting in gradual increase in resistance development rates. Besides, most of the antibiotics are costly and their use is often associated with certain adverse effects on the health of the individuals. Nowadays, the scientific community is focusing more on the search for alternatives for disease therapy. Natural products such as plants, microbes and lichens have been investigated and are found to be promising alternatives. Studies have shown the potential of lichens and their compounds to inhibit a wide range of pathogenic bacteria including antibiotic resistant strains ${ }^{\mathbf{1 - 8}}$. 
Seed is the most important input for producing majority of food crops (about 90\%) as these crops are mainly propagated by seeds. Several pathogenic fungi such as species of Alternaria, Curvularia, Drechslera, Helminthosporium, Fusarium, Pyricularia and Rhizoctonia are often found on seeds. The fungi are known to cause deterioration of seed quality, reduction in nutritive value, reduce the viability of seeds and reduction in seed germination and emergence. The use of synthetic fungicides is widely followed to manage the infections of plants caused by phytopathogenic fungi. These chemical agents are costly and their extensive use is associated with several drawbacks such as residual content in environment (leading to pollution), toxicity to humans and other non-target organisms and emergence of resistant strains of phytopathogenic fungi. Hence, there is a great need for searching alternatives for management of seed-borne and other pathogenic fungi. It is shown that natural products including lichens exhibit growth inhibitory activity against a wide range of phytopathogenic fungi ${ }^{9-15}$.

Lichens are composite organisms comprised of an alga or a cyanobacterium (photobiont) and a fungus (mycobiont) found in an ecologically obligate and stable symbiosis. Lichens are non-vascular cryptogams found distributed in various geographical places of the world such as Antarctic regions, tropical and temperate forests, desserts and high mountains. Lichens occur in any one of the three major growth forms namely crustose, foliose and fruticose. In many parts of the world, lichens are used traditionally as medicine, spice, food and as a source for preparation of perfumes and dyes. Lichens are sensitive to pollution and are considered as the indicators of air pollution. Lichens are known to produce a number of low molecular weight compounds called lichen substances. These compounds are specific to lichens and are not produced by other organisms. Extracts and purified metabolites from lichens exhibit several bioactivities such as antimicrobial, anticancer, antiviral, antioxidant, enzyme inhibitory, antiinflammatory, analgesic and antipyretic activity ${ }^{\mathbf{1 6 - 2 6}}$.

Ramalina Ach. (Ascomycetes: Lecanorales: Ramalinaceae) is one of the important, cosmopolitan and widely studied lichen genera and contains about 200 species. The genus was first described by Acharius. The species of Ramalina are characterized by a fruticose thallus which is attached to the substrate by a holdfast (basal). The thalli are heteromerous, pendent or erect, tufted or sparsed and dichotomously or irregularly branched. The branches may be circular, wide lobed or narrow strap shaped. The members of Ramalina are distributed in diverse habitats such as lowlands, highlands, rainforests and alpines. The species occur on various substrates like rocks, peaty soil, wood, and bark. In fresh conditions, the thalli are greenish-gray to yellowish-gray in color. The color changes to yellowishbrown to dark-brown on drying. The species of Ramalina contain pseudocyphellae. Usnic acid is one of the major metabolites found in the members of Ramalina $^{27-29}$. Several Ramalina species are used traditionally as medicine, food and spice ${ }^{\mathbf{2 3 , 3 0 - 3 3}}$. Various bioactivities such as antimicrobial, antioxidant, enzyme inhibitory, insecticidal, cytotoxic, anthelmintic and immunostimulatory activity are shown by some species of Ramalina ${ }^{5,22,34-38}$. The present study was performed to investigate antibacterial and antifungal activity of three Ramalina species viz. $R$. hossei, $R$. conduplicans and $R$. pacifica.

\section{MATERIALS AND METHODS}

\section{Collection and identification of lichens}

The lichens used in the present study were collected from different places of Shivamogga district, Karnataka, India during January-February 2017. The collected lichens were identified on the basis of morphological, anatomical and color tests. The color tests were carried out on cortex and medulla by using $10 \%$ potassium hydroxide $(\mathrm{K})$, Steiner's stable para-phenylenediamine solution $(\mathrm{P})$ and calcium hypochlorite solution $(\mathrm{C})$. Thin layer chromatography (TLC) was used to detect the secondary metabolites present in lichens. Solvent system A (Benzene: 1, 4-Dioxane: Acetic acid) was used as developing solvent ${ }^{27,39,40}$. Details on the growth form, substratum and the place of collection of Ramalina are shown in Table 1. Characteristics of thallus and the result of color test and TLC of the selected Ramalina species is shown in Table 2.

\section{Extraction}

The dried and powdered lichen materials were extracted using methanol by maceration process. The lichen powders $(10 \mathrm{~g})$ were left in methanol $(100 \mathrm{ml})$ for 48 hours in stoppered containers. The containers were stirred occasionally. The contents were filtered through Whatman filter paper and the filtrates were evaporated to dryness. The crude lichen extracts were stored in refrigerator $^{14,41}$.

Table 1: Growth form and place of collection of lichens

\begin{tabular}{|l|l|l|}
\hline Lichen & Growth form and Substrate & Place of collection \\
\hline Ramalina pacifica Asahina & Fruticose; Areca catechu & Shikaripura \\
\hline Ramalina conduplicans Vain. & Fruticose; Areca catechu & Koodli \\
\hline Ramalina hossei Vain. & Fruticose; Gardenia gummifera & Sagara \\
\hline
\end{tabular}


Table 2: Thallus features, Color test and TLC of Ramalina species

\begin{tabular}{|l|l|c|c|}
\hline \multicolumn{1}{|c|}{ Lichen } & \multicolumn{1}{|c|}{ Thallus characteristics } & Color test & $\begin{array}{c}\text { Secondary } \\
\text { metabolites }\end{array}$ \\
\hline \multirow{5}{*}{ R.conduplicans } & $\begin{array}{l}\text { Thallus corticolous, about 6-8cm long, branched (branches 2-3mm } \\
\text { wide), erect to decumbent, greenish grey in color; upper side } \\
\text { smooth and scarcely pseudocyphellate; lower side rugose, with } \\
\text { raised, round to oblong, prominent pseudocyphellae; soredia } \\
\text { absent; chondroid tissue uneven in thickness; medulla solid; } \\
\text { apothecia about 2mm in diameter, ascospores straight or curved. }\end{array}$ & $\begin{array}{c}\text { Cortex K-; } \\
\text { Medulla K-, KC -, } \\
\text { Pd+ yellow }\end{array}$ & $\begin{array}{c}\text { Usnic acid, } \\
\text { Salazinic acid, } \\
\text { Sekikaic acid }\end{array}$ \\
\hline \multirow{5}{*}{ R.pacifica } & $\begin{array}{l}\text { Thallus corticolous, about 10cm long, pendulous, brownish grey } \\
\text { in color, branched (branches 1-2mm wide), anastomosing, apically } \\
\text { attenuate; striate, pseudocyphellae marginal; soralia laminal to } \\
\text { marginal; chondroid tissue uniform, not cracked; medulla solid. }\end{array}$ & $\begin{array}{c}\text { Medulla K-, } \\
\text { C- }\end{array}$ & $\begin{array}{c}\text { Usnic acid, } \\
\text { Salazinic acid }\end{array}$ \\
\hline R.hossei & $\begin{array}{l}\text { Thallus corticolous, about 5-6cm long, tufted, erect, yellowish } \\
\text { grey in color, branched (branches about 2mm wide), nervosa; } \\
\text { marginal pseudocyphellae turn into soralia; soredia granular; } \\
\text { chondroid tissue cracked; medulla solid; apothecia 1mm in } \\
\text { diameter; ascospores straight or slightly curved. }\end{array}$ & $\begin{array}{c}\text { Cortex K+ } \\
\text { yellow; } \\
\text { Medulla K-, } \\
\text { C- }\end{array}$ & $\begin{array}{c}\text { Usnic acid, } \\
\text { Sekikaic acid }\end{array}$ \\
\hline
\end{tabular}

\section{Antibacterial activity of Ramalina species}

Agar well diffusion method was used to evaluate antibacterial potential of three Ramalina species. The test bacteria included two Gram positive bacteria (Bacillus subtilis NCIM 2063 and Bacillus cereus NCIM 2016) and two Gram negative bacteria (Escherichia coli NCIM 2065 and Pseudomonas aeruginosa NCIM 2200). The bacteria were procured from NCL, Pune, India. The pure cultures of test bacteria were maintained on nutrient agar slants under refrigeration condition. The test bacteria were seeded into sterile nutrient broth tubes and incubated overnight at $37^{\circ} \mathrm{C}$. The broth cultures of test bacteria were inoculated all over the surface of sterile nutrient agar plates by using sterile cotton swabs. Using sterilized cork borer, wells of $8 \mathrm{~mm}$ diameter were punched in the inoculated plates. The wells were labeled and filled with $100 \mu 1$ of lichen extract $(20 \mathrm{mg} / \mathrm{ml}$ of DMSO), reference antibiotic (Chloramphenicol; $1 \mathrm{mg} / \mathrm{ml}$ of sterile distilled water) and DMSO. The plates were incubated for 24 hours at $37^{\circ} \mathrm{C}$. The zones of inhibition were measures using a ruler ${ }^{14,41}$.

\section{Antifungal activity of Ramalina species}

The test fungi used were Alternaria sp., Curvularia sp. and Fusarium sp. These fungi were isolated previously from sorghum seeds. The fungi were maintained on Potato dextrose agar slants under refrigerated condition. The antifungal activity of extract of Ramalina species was carried out by Poisoned food technique. The test fungi were inoculated into control (without extract) and poisoned Potato dextrose agar $(0.5 \mathrm{mg}$ extract $/ \mathrm{ml}$ of medium) plates aseptically. The plates were incubated for 5 days at room temperature followed by determining the size of colonies (diameter) in mutual perpendicular directions using a ruler. The antifungal effect of extracts was determined using the formula:

Inhibition of mycelial growth $(\%)=(\mathrm{Dc}-\mathrm{Dt} / \mathrm{Dc}) \mathrm{x}$ 100 , where Dc and Dt refers to diameter of fungal colonies on control plates and poisoned plates respectively ${ }^{14,41}$.

\section{Statistical analysis}

All experimental protocols were carried out in triplicates $(n=3)$. The results are represented as Mean \pm Standard deviation (S.D).

\section{RESULTS AND DISCUSSION}

In the present study, we investigated the antibacterial potential of three Ramalina species by agar well diffusion assay. The extracts from selected lichens were shown to inhibit the growth of bacteria as evidenced by the presence of zones of inhibition around the wells. Among bacteria, B. cereus and E. coli exhibited highest and least susceptibility respectively to lichen extracts. Next to $B$. cereus, $P$. aeruginosa exhibited high susceptibility to lichen extracts. Reference antibiotic displayed high inhibition of test bacteria when compared to Ramalina species. The diluent DMSO did not cause inhibition of any test bacteria (Table 3).

Table 3: Antibacterial activity of Ramalina species

\begin{tabular}{|l|c|c|c|c|}
\hline \multirow{2}{*}{ Treatment } & \multicolumn{4}{|c|}{ Zone of inhibition in cm (Mean \pm S.D; $=3$ ) } \\
\cline { 2 - 5 } & E. coli & P. aeruginosa & B. subtilis & B. cereus \\
\hline R. pacifica & $1.60 \pm 0.00$ & $2.16 \pm 0.05$ & $1.76 \pm 0.05$ & $2.70 \pm 0.00$ \\
\hline R. conduplicans & $1.43 \pm 0.05$ & $2.00 \pm 0.00$ & $1.50 \pm 0.00$ & $2.60 \pm 0.10$ \\
\hline$R$. hossei & $1.30 \pm 0.00$ & $1.30 \pm 0.10$ & $1.33 \pm 0.05$ & $2.20 \pm 0.00$ \\
\hline Antibiotic & $2.66 \pm 0.05$ & $2.90 \pm 0.00$ & $3.40 \pm 0.00$ & $3.66 \pm 0.05$ \\
\hline DMSO & $0.00 \pm 0.00$ & $0.00 \pm 0.00$ & $0.00 \pm 0.00$ & $0.00 \pm 0.00$ \\
\hline
\end{tabular}


Among lichens, $R$. pacifica exhibited marked antibacterial potential when compared to other two species of Ramalina. In a study, Hoskeri et al. ${ }^{5}$ showed the potential of extract of $R$. pacifica to inhibit clinical isolates. In another study, Kekuda et $a l^{\mathbf{4 2}}$ showed inhibitory activity of $R$. pacifica against reference bacteria. Next to $R$. pacifica, $R$. conduplicans was found to exhibit marked antibacterial activity against Gram positive and Gram negative bacteria. In an earlier study, Kambar et $a .^{\mathbf{1 4}}$ showed concentration dependent inhibitory activity of solvent extracts of $R$. conduplicans against Gram positive and Gram negative bacteria. The study of Devi et al. ${ }^{\mathbf{4 3}}$ showed that methanol extract of $R$. conduplicans was effective in inhibiting bacteria to higher extent when compared to other solvent extracts. In the present study, the antibacterial activity observed against test bacteria was least in case of $R$. hossei. Extract of $R$. hossei caused marked inhibitory activity against $B$. cereus while inhibition of other test bacteria by extract was more or less similar. In a previous study, Vinayaka et $a l .{ }^{44}$ found marked antibacterial activity of methanol extract of $R$. hossei against test bacteria. In another study, Kekuda et $a l^{\mathbf{4 2}}$ revealed potent antibacterial activity of extract of $R$. hossei against Gram positive and Gram negative bacteria. Recently, Kekuda and Vinayaka ${ }^{8}$ showed the potential of $R$. hossei, $R$. conduplicans and $R$. pacifica to inhibit clinical isolates of Streptococcus mutans. Antibacterial activity of other species of Ramalina such as $R$. farinacea $^{6,45}, \quad R$. roesleri ${ }^{46}, R$. canariensis $^{47}, \quad R$ chondrina $^{47}, \quad R$. fastigiata $^{4,47}, \quad R$. fraxinea $^{\mathbf{4 , 4 7},}, R$. pollinaria $^{4}, R$. polymorpha ${ }^{4}, R$. capitata $^{4}, R$. menziesii ${ }^{48}$ have been investigated.

In the present study, we determined antifungal potential of three Ramalina species by Poisoned food technique. Extract of all three Ramalina species were effective in inhibiting test fungi but to a varied extent. Considerable reduction in the mycelial growth of test fungi was observed in poisoned potato dextrose agar plates. Antifungal potential of Ramalina species was in the order: $R$. hossei $>R$. conduplicans $>R$. pacifica. The susceptibility of test fungi to extracts was in the order: Alternaria sp. > Curvularia sp. > Fusarium sp (Table 4).

Table 4: Antifungal activity of Ramalina species

\begin{tabular}{|c|c|c|c|}
\hline \multirow{2}{*}{ Treatment } & \multicolumn{3}{|c|}{$\begin{array}{c}\text { Colony diameter in cm }(\text { Mean } \pm \text { S.D; } \\
n=3)\end{array}$} \\
\hline & $\begin{array}{l}\text { Alternaria } \\
\text { sp. }\end{array}$ & $\begin{array}{l}\text { Curvularia } \\
\text { sp. }\end{array}$ & $\begin{array}{c}\text { Fusarium } \\
\text { sp. }\end{array}$ \\
\hline Control & $5.10 \pm 0.00$ & $4.70 \pm 0.10$ & $3.46 \pm 0.05$ \\
\hline R. hossei & $0.66 \pm 0.05$ & $1.80 \pm 0.10$ & $2.20 \pm 0.00$ \\
\hline R. pacifica & $1.80 \pm 0.00$ & $2.20 \pm 0.00$ & $2.30 \pm 0.10$ \\
\hline R. conduplicans & $1.30 \pm 0.00$ & $2.13 \pm 0.05$ & $2.20 \pm 0.10$ \\
\hline
\end{tabular}

R. hossei inhibited Alternaria sp. to higher extent (87.05\% inhibition) followed by Curvularia sp. (61.70\% inhibition) and Fusarium sp (36.41\% inhibition). In previous studies by Kambar et al. ${ }^{\mathbf{4 9}}$ and Kekuda et al. ${ }^{\mathbf{4 2}}$, the extracts of $R$. hossei were shown to exhibit marked antifungal activity against phytopathogenic fungi. In this study, $R$. pacifica was shown to cause inhibition of
Alternaria sp. to higher extent $(64.70 \%$ inhibition) followed by Curvularia sp. (53.19\% inhibition) and Fusarium sp. (33.52\% inhibition). In an earlier study, Kekuda et ll $^{42}$ showed potent antifungal activity of $R$. pacifica against a panel of phytopathogenic fungi with marked inhibitory activity against Colletotrichum capsici. It was observed in the present study that the extract of $R$. conduplicans inhibited Alternaria sp. to higher extent $(74.50 \%$ inhibition) followed by Curvularia sp. (54.68\% inhibition) and Fusarium sp ( $36.41 \%$ inhibition). In a similar study, Kambar et al. ${ }^{\mathbf{1 4}}$ showed antifungal effect of different solvent extracts of $R$. conduplicans against a panel of fungi from plant sources. In another study, Devi et $a l^{\mathbf{4 3}}$ showed the potential of various solvent extracts of $R$. conduplicans to inhibit phytopathogenic fungi. Studies have shown the potential of other species of Ramalina to exhibit antifungal activity. In an earlier study, Shivanna and Garampalli $^{\mathbf{5 0}}$ showed the potential of $R$. farinacea to inhibit Fusarium oxysporum and $F$. solani. The study of Goel et $a .^{\mathbf{1 2}}$ showed the potential of $R$. roesleri to inhibit a range of phytopathogenic fungi including Rhizoctonia bataticola.

The lichens produce a number of secondary metabolites that seldom occur in other organisms. These compounds are called lichen substances and till now >1000 lichen secondary metabolites have been identified. Many of these compounds are low molecular weight phenolic compounds and are known to protect the lichens by functioning as sunscreen, anti-herbivore etc ${ }^{\mathbf{2 1 , 2 6}}$. TLC is one of the techniques used to detect the secondary metabolites present in lichen extracts. In the present study, the thin layer chromatogram of the Ramalina species showed the presence of usnic acid in all species. Salazinic acid was present in $R$. conduplicans and $R$. pacifica while sekikaic acid was present in $R$. hossei and $R$. conduplicans. Antimicrobial activity of usnic $\operatorname{acid}^{18,35,51}$, salazinic acid ${ }^{52}$ and sekikaic acid ${ }^{26,35,53}$ have been reported. The study of Cansaran et $a l .^{4}$ showed a direct correlation between the amount of usnic acid and the antimicrobial activity observed.

\section{CONCLUSIONS}

The Ramalina species selected in this study were shown to exhibit marked antibacterial and antifungal activity. These lichens can be used to develop formulations or agents which can be used to treat infectious diseases and to manage seed-borne fungal diseases. The observed inhibitory activity of lichens could be ascribed to the presence of bioactive metabolites such as usnic acid, salazinic acid and sekikaic acid which have been detected by TLC.

\section{CONFLICTS OF INTEREST}

None declared

\section{ACKNOWLEDGEMENTS}

Authors are thankful to Head of the department of Microbiology and Principal, S.R.N.M.N College of Applied Sciences and N.E.S, Shivamogga for providing facilities and moral encouragement to conduct work. 


\section{REFERENCES}

1. Esimone CO, Adikwu MU, Susceptibility of some clinical isolates of Staphylococcus aureus to bioactive column fractions from the lichen Ramalina farinacea (L.), Phytotherapy Research, 2002, 16(5), 494-496.

2. Wright GD, Mechanisms of resistance to antibiotics, Current Opinion in Chemical Biology, 2003, 7, 563-569.

3. Elo H, Matikainen J, Pelttari E, Potent activity of the lichen antibiotic (+)-usnic acid against clinical isolates of vancomycin-resistant enterococci and methicillin resistant Staphylococcus aureus, Naturwissenschaften, 2007, 94(6), 465-468.

4. Cansaran D, Atakol O, Halici GM, Aksoy A, HPLC analysis of usnic acid in some Ramalina species from Anatolia and investigation of their antimicrobial activities, Pharmaceutical Biology, 2007, 45(1), 77-81.

5. Hoskeri JH, Krishna V, Amruthavalli C, Effects of extracts from lichen Ramalina pacifica against clinically infectious bacteria, Researcher, 2010, 2(3), 81-85.

6. Agboke AA, Esimone CO, Attama AA, Mohmoh MA, In vitro evaluation of the interaction between methanol extract of the lichen, Ramalina farinacea and ampicillin against clinical isolates of Staphylococcus aureus, International Journal of Phytopharmacy Research, 2011, 2(1), 35-39.

7. Vivek MN, Kambar Y, Manasa M, Kekuda PTR, Vinayaka KS, Radical scavenging and antibacterial activity of three Parmotrema species from Western Ghats of Karnataka, India, Journal of Applied Pharmaceutical Science, 2014, 4(3), 86-91.

8. Kekuda PTR, Vinayaka KS, In vitro anticaries activity of some macrolichens of Karnataka, India, International Journal of Pharma Research and Health Sciences, 2016, 4(3), 12441248.

9. Shahi SK, Shukla AC, Dikshit A, Uperti DK, Broad spectrum antifungal properties of the lichen Heterodermia leucomela, Lichenologist, 2001, 33, 177-179.

10. Panea C, Piccolo A, Spaccini R, Celanoc G, Villeccoa D, Zaccardellia M, Agricultural waste-based composts exhibiting suppressivity to diseases caused by the phytopathogenic soil-borne fungi Rhizoctonia solani and Sclerotinia minor, Applied Soil Ecology, 2013, 65, 43-51.

11. Wei X, Jeon H, Han KS, Koh YJ, Hur J, Antifungal activity of lichen-forming fungi against Colletotrichum acutatum on hot pepper, The Plant Pathology Journal, 2008, 24(2), 202206.

12. Goel M, Sharma PK, Dureja P, Rani A, Uniyal PL, Antifungal activity of extracts of the lichens Parmelia reticulata, Ramalina roesleri, Usnea longissima and Stereocaulon himalayense, Archives of Phytopathology and Plant Protection, 2011, 44(13), 1300-1311.

13. Tiwari P, Rai H, Upreti DK, Trivedi S, Shukla P, Assessment of antifungal activity of some Himalayan foliose lichens against plant pathogenic fungi, American Journal of Plant Science, 2011, 2, 841-846.

14. Kambar Y, Vivek MN, Manasa M, Kekuda PTR, Onkarappa $\mathrm{R}$, Antimicrobial activity of Ramalina conduplicans Vain. (Ramalinaceae), Science Technology and Arts Research Journal, 2014, 3(3), 57-62.

15. Kekuda PTR, Raghavendra HL, Antifungal activity of Helichrysum buddleioides DC. against seed borne fungi, EC Microbiology, 2017, 6(2), 54-59.

16. Sanders WB, Lichens: The interface between mycology and plant morphology, BioScience, 2001, 51(12), 1025-1035.

17. Garty J, Levin $\mathrm{T}$, Cohen $\mathrm{Y}$, Lehr $\mathrm{H}$, Biomonitoring air pollution with the desert lichen Ramalina maciformis, Physiologia Plantarum, 2002, 115(2), 267-275.

18. Tay T, Türk AÖ, Yılmaz M, Türk H, Kıvanc M, Evaluation of the antimicrobial activity of the acetone extract of the lichen Ramalina farinacea and its (+)-usnic acid, norstictic acid, and protocetraric acid constituents, Zeitschrift für Naturforschung C, 2004, 59, 384-388.

19. Ranković B, Mišić M, The antimicrobial activity of the lichen substances of the lichens Cladonia furcata, Ochrolechia androgyna, Parmelia caperata and Parmelia conspresa, Journal Biotechnology and Biotechnological Equipment, 2008, 22(4), 1013-1016.

20. Karthikaidevi G, Thirumaran G, Manivannan K, Anantharaman P, Kathiresan K, Balasubramanian $\mathrm{T}$, Screening of the antibacterial properties of lichen Roccella belangeriana (Awasthi) from Pichavaram mangrove (Rhizophora sp.), Advances in Biological Research, 2009, 3(3-4), 127-131.

21. Molnár K, Farkas E, Current results on biological activities of lichen secondary metabolites: a review, Zeitschrift für Naturforschung C, 2010, 65(3-4), 157-173.

22. Verma N, Behera BC, Sharma BO, Glucosidase inhibitory and radical scavenging properties of lichen metabolites salazinic acid, sekikaic acid and usnic acid, Hacettepe Journal of Biology and Chemistry, 2012, 40(1), 7-21.

23. Upreti DK, Bajpai R, Nayaka S, Ethnobotanically important Indian lichens, Ethnobotany, 2013, 25, 33-40.

24. Shah NC, Lichens of commercial importance in India, The Scitech Journal, 2014, 1(2), 32-36.

25. Cornejo A, Salgado F, Caballero J, Vargas R, Simirgiotis M, Areche C, Secondary metabolites in Ramalina terebrata detected by UHPLC/ESI/MS/MS and identification of Parietin as Tau protein inhibitor, International Journal of Molecular Sciences, 2016, 17(8), 1303.

26. Gunasekaran S, Rajan VP, Ramanathan S, Murugaiyah V, Samsudin MW, Din LB, Antibacterial and antioxidant activity of lichens Usnea rubrotincta, Ramalina dumeticola, Cladonia verticillata and their chemical constituents, Malaysian Journal of Analytical Sciences, 2016, 20, 1-13.

27. Awasthi DD, A compendium of the macrolichens from India, Nepal and Sri Lanka, Bishen Singh Mahendra Pal Singh, Dehra Dun, India, 2007.

28. Lin C, A preliminary study of the lichen genus Ramalina at Mt. Yangtou, Hualien County, Eastern Taiwan, Collection and Research, 2009, 22, 131-134

29. Oh S, Wang XY, Wang LS, Liu PG, Hur J, A note on the lichen genus Ramalina (Ramalinaceae, Ascomycota) in the Hengduan Mountains in China, Mycobiology, 2014, 42(3), 229-240.

30. Ghorbani A, Langenberger G, Sauerborn J, A comparison of the wild food plant use knowledge of ethnic minorities in Naban River Watershed National Nature Reserve, Yunnan, SW China, Journal of Ethnobiology and Ethnomedicine, 2012, 8, 17.

31. Sigdel SR, Rokaya MB, Timsina B, Plant inventory and ethnobotanical study of Khimti hydropower project, central Nepal, Scientific World, 2013, 11(11), 105-112.

32. Liu B, Liu Y, Li J, Gu R, Wujisiguleng, Li P, Li F, Aromatic lichen resources in Guizhou Province, China, Medicinal and Aromatic Plants, 2014, 3, 146.

33. Devkota S, Chaudhary RP, Werth S, Scheidegger C, Indigenous knowledge and use of lichens by the lichenophilic communities of the Nepal Himalaya, Journal of Ethnobiology and Ethnomedicine, 2017, 13, 15.

34. Carlos IZ, Carli CBA, Maia DCG, Benzatti FP, Lopes FCM, Roese FM, Watanabe M, Micheletti AC, dos Santos LC, Vilegas W, Honda NK, Immunostimulatory effects of the phenolic compounds from lichens on nitric oxide and hydrogen peroxide production, Brazilian Journal of Pharmacognosy, 2009, 19(4), 847-852.

35. Dias DA, Urban S, Phytochemical investigation of the Australian lichens Ramalina glaucescens and Xanthoria parietina, Natural Product Communications, 2009, 4(7), 959964.

36. Vinayaka KS, Karthik S, Nandini KC, Kekuda PTR, Amylase inhibitory activity of some macrolichens of Western Ghats, Karnataka, India, Indian Journal of Novel Drug Delivery, 2013, 5(4), 225-228.

37. Moreira ASN, Braz-Filho R, Mussi-Dias V, Vieira IJC, Chemistry and biological activity of Ramalina lichenized fungi, Molecules, 2015, 20, 8952-8987.

38. Moreira ASN, Fernandes ROS, Lemos FJA, Braz-Filho R, Vieira IJC, Larvicidal activity of Ramalina usnea lichen 
against Aedes aegypti, Brazilian Journal of Pharmacognosy, 2016, 26, 530-532.

39. Culberson CF, Kristinsson H, A standardized method for the identification of lichen products, Journal of Chromatography, 1970, 46, 85-93.

40. Culberson $\mathrm{CF}$, Improved conditions and new data for the identification of lichen products by a standardized thin layer chromatographic method, Journal of Chromatography, 1972, 72, 113-125.

41. Raghavendra HL, Kekuda PTR, Akarsh S, Ranjitha MC, Ashwini HS, Phytochemical analysis, antimicrobial and antioxidant activities of different parts of Pleocaulus sessilis (Nees) Bremek (Acanthaceae), International Journal of Green Pharmacy, 2017, 11(2), 98-107.

42. Kekuda PTR, Ranjitha MC, Firdose G, Vidya P, Vinayaka KS, Antimicrobial activity of selected corticolous macrolichens, Science, Technology and Arts Research Journal, 2015, 4(3), 169-174.

43. Devi AB, Mohabe S, Nayaka S, Reddy M, In-vitro antimicrobial activity of lichen Ramalina conduplicans Vain. collected from Eastern Ghats, India, Science Research Reporter, 2016, 6(2), 99-108.

44. Vinayaka KS, Kekuda PTR, Swathi D, Kumar PSV, Studies on chemical composition and in vitro antibacterial activity of solvent extracts of lichen Ramalina hossei Vain. (Ramalinaceae), Biotechnology: An Indian Journal, 2009, 3(4), 309-311.

45. Chahra D, Ramdani M, Lograda T, Chalard P, Figueredo G, Chemical composition and antimicrobial activity of Evernia prunastri and Ramalina farinacea from Algeria, Issues in Biological Sciences and Pharmaceutical Research, 2016, 4(5), 35-42.
46. Sisodia R, Goel M, Verma S, Rani A, Dureja P, Antibacterial and antioxidant activity of lichen species Ramalina roesleri, Natural Product Research, 2013, 27(23), 2235-2239.

47. Sesal C, Çobanoğlu G, Karaltı İ, Açıkgöz B, In vitro antimicrobial potentials of four Ramalina lichen species from Turkey, Current Research in Environmental and Applied Mycology, 2016, 6(3), 202-209.

48. Shrestha G, St. Clair LL, Anti-microbial activity of extracts from two lichens- Ramalina menziesii and Usnea lapponica, Bulletin of the California Lichen Society, 2013, 20(1), 5-10.

49. Kambar Y, Vivek MN, Manasa M, Vinayaka KS, Mallikarjun N, Kekuda PTR, Antimicrobial activity of Leptogium burnetiae, Ramalina hossei, Roccella montagnei and Heterodermia diademata, International Journal of Pharmaceutical and Phytopharmacological Research, 2014, 4(3), 164-168.

50. Shivanna R, Garampalli RH, Investigation of macrolichens for antifungal potentiality against phytopathogens, Indo American Journal of Pharmaceutical Research, 2016, 6(4), 5290-5296.

51. Ghione M, Parrello D, Grasso L, Usnic acid revisited, its activity on oral flora, Chemioterapia, 1988, 7(5), 302-305.

52. Candan M, Yılmaz M, Tay T, Erdem M, Türk AÖ, Antimicrobial activity of extracts of the lichen Parmelia sulcata and its Salazinic acid constituent8, Zeitschrift für Naturforschung C, 2007, 62, 619-621.

53. Thadhani VM, Choudhary IM, Khan S, Karunaratne V, Antimicrobial and toxicological activities of some depsides and depsidones, Journal of National Science Foundation Sri Lanka, 2012, 40(1), 43-48. 